\title{
Invasive Exotic Rangeland Weeds: A Glimpse at Some of Their Native Habitats
}

\author{
VLADIMIR KOSTIVKOVSKY AND JAMES A. YOUNG
}

$\Lambda$ nyone driving through the Great Basin must be impressed with the tremendous environmental impact of invasive exotic weeds on the former sagebrush/bunchgrass rangelands. There are exotic plant species in the Great Basin that are valuable forage species. These plants are rarely self-invasive, meaning they cannot spread with out the help of humans. Exotic species that can spread without the conscious efforts of humans are usually serious weed species. Cheatgrass is perhaps the most visible example of the impact of exotic species, but there are a host of others that collectively have changed plant succession over millions of acres of rangeland.

At research field days, producer gatherings, and at technical meetings it is common to hear the question, "Where did these weeds come from and what do they look like in their native habitat?" The center of origin for many of these species is the temperate deserts of Asia.

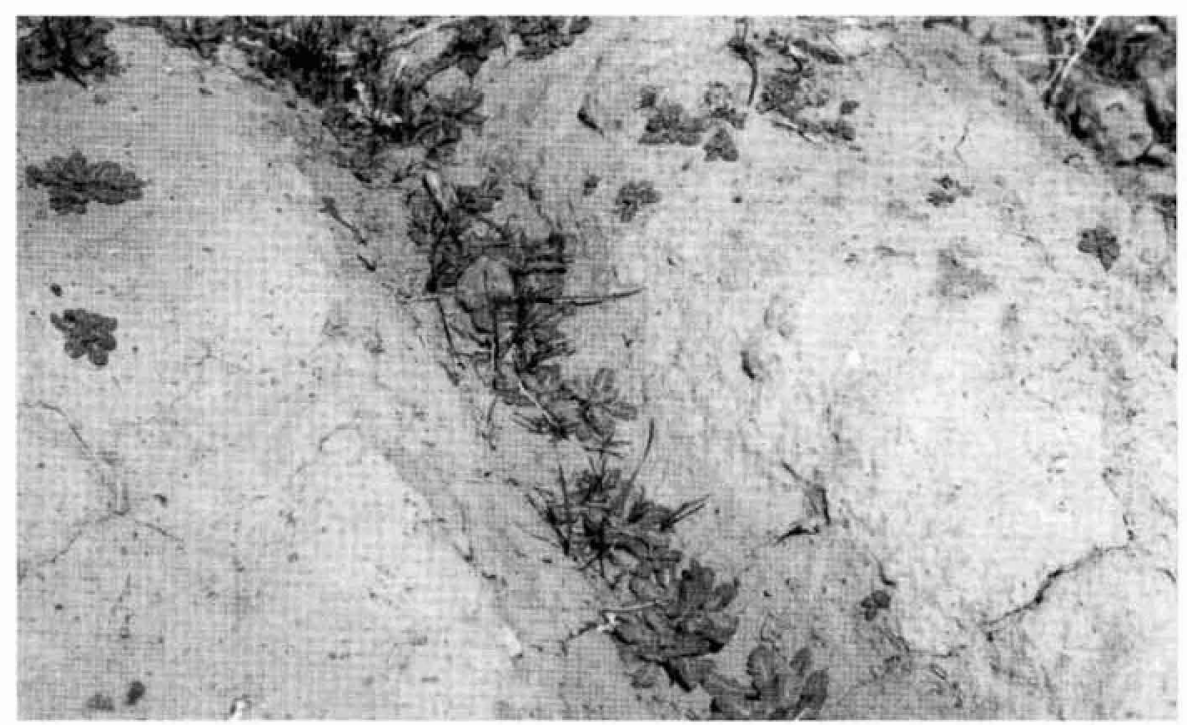

Tumble mustard seedling growing in a drill furrow with crested wheatgrass seedlings. Tumble mustard is an exotic weed accidentally introduced from Asia. In former sagebrush/bunchgrass communities in the Great Basin, tumble mustard is suppressed by cheatgrass. Once the cheatgrass is controlled to allow perennial grass seedlings to establish, tumble mustard seeds germinate from the seedbank.

\section{Floristic Regions}

Many of the exotic weeds currently thriving in the Great Basin of western North America originated from Central Asia. Central Asia includes the semiarid regions from northern China on the east to the $\mathrm{Ob}$ River on the west. It includes the northwestern provinces of China, Mongolia, and southern Siberia between the Ob River and Lake Bajkal. Botanically it is considered the center of origin for many groups of plants and is the home of abundant endemic species.

The Central Asian floristic region is nearly a synonymous environment to the Intermountain Area between the SierraCascade and Rocky Mountains in western North America. Portions of both areas are temperate deserts with areas of salty soils. Both areas feature vast landscapes dominated by semi-woody species of sagebrush and at lower elevations chenopod shrubs. Some genera, such as sagebrush, saltbushes, kochia, 


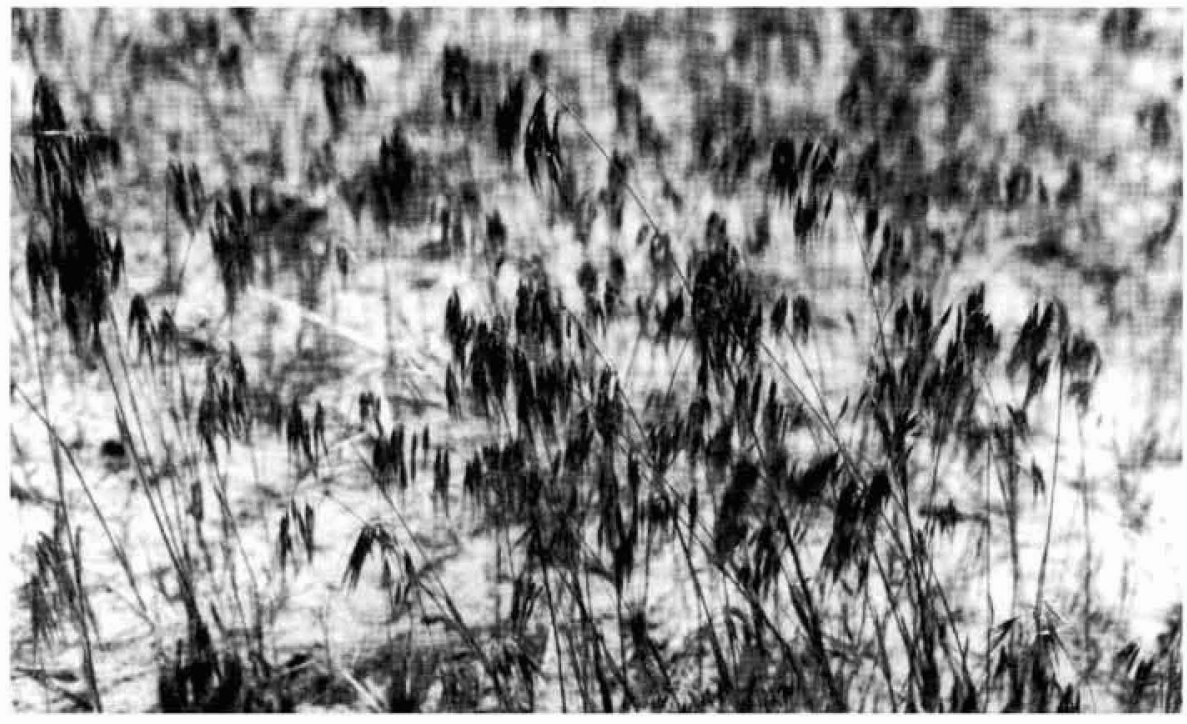

Cheatgrass is an exotic annual that was accidentally introduced to western North America. It now dominates millions of acres of formerly sagebrush/bunchgrass rangeland. Cheatgrass closes communities to the establishment of seedlings of perennial species through competition for water. In wet years, cheatgrass produces an abundance of early maturing, fine textured fuel which increases the chance of ignition and rate of spread of wildfires.

occur before the onset of winter. Cheatgrass could have been brought to America as a contaminant of crop seeds from the Lower Volga and North Caucasus regions, the Ukraine, Romania, and Balkan countries. It could also have been a wool contaminant of Asiatic sheep from Middle Asia.

This plant was evidently widely distributed in arid and semi-arid rangelands of Eurasia before the beginning of cattle husbandry. All of the native wild large herbivores of Eurasia are typical consumers of cheatgrass herbage on desert ranges. These include saiga antelope, onagres, gazelles, and Nubian goats. Camels also consume cheatgrass herbage, but they prefer to browse on woody plants or to graze perennial grasses. Perhaps, these native herbivores contributed to the widespread distribution of cheatgrass before the advent of livestock domestication.

Near mono-cultures of cheatgrass and wildfires associated with accumulations of cheatgrass herbage are seldom, if ever, a feature of the Central Asian environments. Natural insect and disease pests, grazing intensity, and nitrogen levels in the soils probably all contribute to relative lack of dominance of cheatgrass in its native habitat.

\section{Russian Thistle}

Probably native to Asia, Russian thistle has become distributed around the world. Salsola targus L., S. australis R. Brown, S. iberica Sennen and Pau, $S$. kali var. tenuifolia Tausch, S. pestifer Nelson-are just some of the scientific names that have been proposed for this plant. The taxon Salsola australis Robert Brown was first published for material collected in Australia in 1810 where it is obviously an introduced species. The taxon Salsola pestifer A. Nelson was proposed for material collected in the Red Desert of Wyoming. The weed was first introduced to the American west in 1877 in a shipment of flax seed from Russia sent to Bon Humme County, South Dakota. In the American west this weed was popularly known as tumble weed because at maturity the stems break at the soil surface and are tumbled across the landscape by winds, distributing seeds. The genus Salsola is widespread in all deserts, semi-arid and steppe zones of Eurasia. Almost all species of this genus prefer environments with salt affected soils.

Russian thistle is a major weed in many forms of cereal grain production. Russian thistle is so closely associated with human activity it is difficult to determine the location where it was ever a "native" species. On rangelands it is often the first species to appear on disturbed sites. Russian thistle was the first species to invade ground zero of atmospheric test of atomic bombs in the southern Nevada Deserts.

There are about 100 species of Salsola. Several of these species are woody perennials native to Central Asia. Perhaps, lurking among these species is a self invasive species capable of establishing in cheatgrass dominated sites in the Great Basin if it is accidentally introduced.

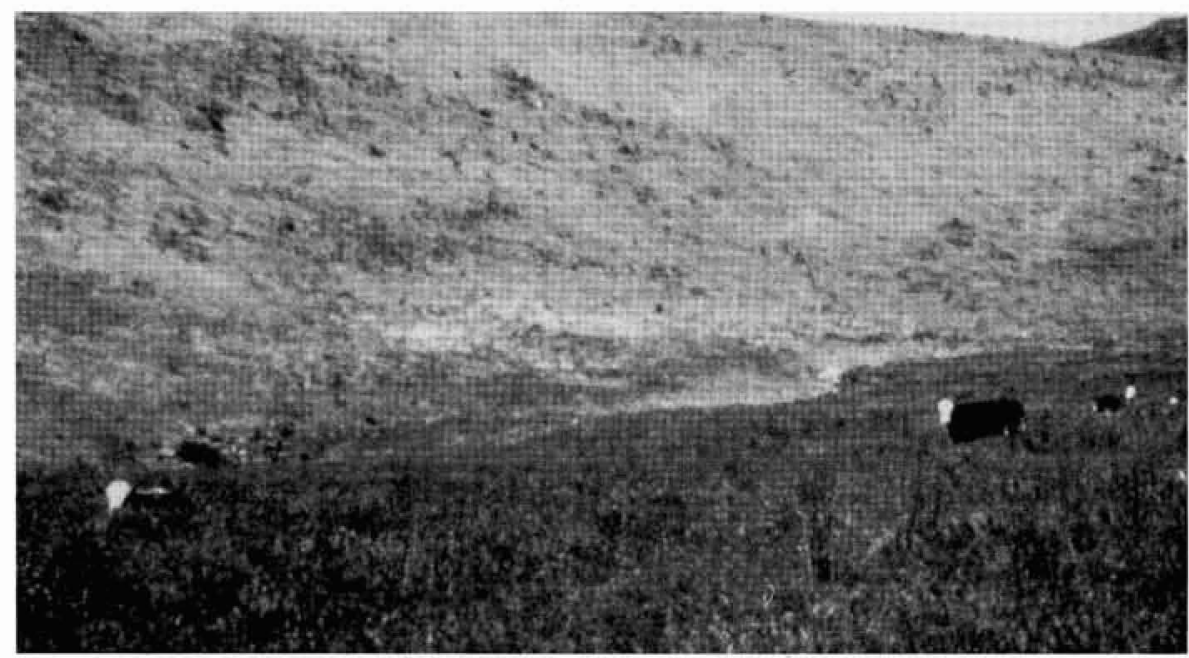

Emigrant Pass, Elko County, Nevada in 1964. Exceptional amounts and favorable periodicity of spring rains produced abundant growth of cheatgrass. In August of that year Emigrant Pass and hundreds of thousands of acres of cheatgrass dominated rangelands burned in northern Nevada. In 1999, about 1.6 million acres of rangeland burned in northern Nevada including the Emigrant Pass site. 


\section{Barbwire Russian Thistle}

Barbwire Russian thistle is the recent introduction to the deserts of the Intermountain Area of western North America. Here it is a weed of rangelands and not an agronomic weed. Barbwire Russian thistle is most abundant in Middle Asia and less frequent in Central Asia. It is a typical plant of deserts with sandy soils such as the Karakum or Kysylkum. The surface soils of these deserts are usually not salt affected because they are highly permeable and readily leached. Barbwire Russian thistle prefers to grow under the canopies of desert trees and shrubs such as Haloxylon, Tamarix, Salsola, and Ephedra among others. These woody species have roots in salt affected horizons at depth in the soil profile. The bioconcentrates in leaves and fruits that accumulate in the sub-canopy area create favorable growing conditions for barbwire Russian thistle.

Barbwire Russian thistle is considered a good fodder for sheep and camels. It begins growth in May to June and remains green until late autumn. In September-October plants are covered by abundant seeds which are considered nutritious for cattle. Barbwire Russian thistle occurs on the margins of cotton fields located along rivers flowing to the Aral Sea.

Barbwire Russian thistle could have been brought to America as a contaminant of cotton from India or in wool from anywhere within the natural range of the species. The location is probably not the original point of introduction, but the weed was first widely recognized in the United States, on the Department of Energy, Atomic Test Site in southern Nevada.

\section{Halogeton}

Halogeton is a typical halophytous plant (plant of salty soils). It grows in all of the salt deserts of Iran and on the eastern shores of the Caspian Sea. The typical environment of halogeton is islands of silty or loamy soils within sandy deserts. Such areas are known by the Turkish word takyrs. They are similar to what are called playas in western

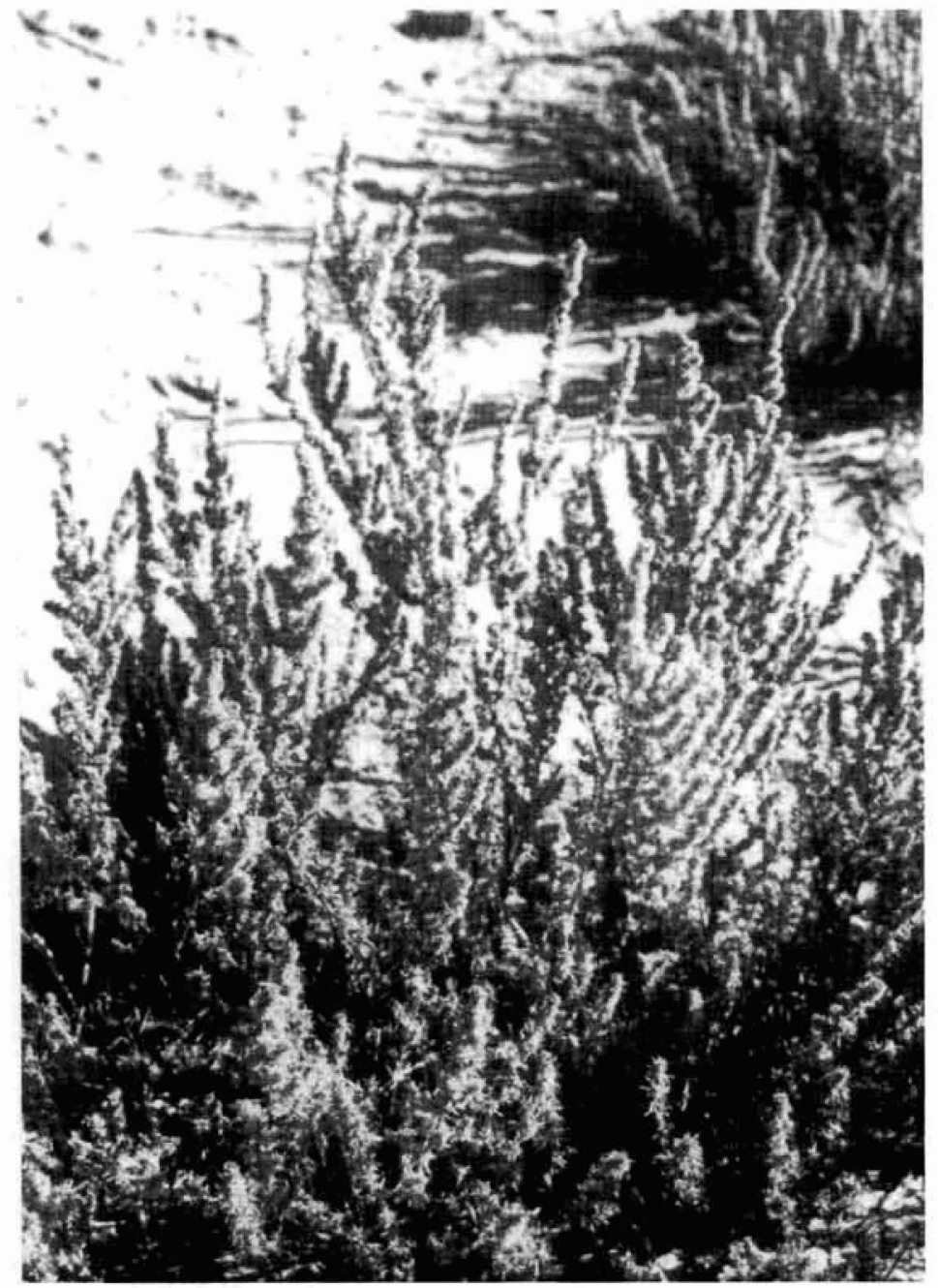

Halogeton plant in fruit. This exotic species was the center of attention on Great Basin rangelands in the 1940 and 1950s. The annual species is highly toxic to sheep.

North America. The silts form impervious layers from which runoff water evaporates leaving salts. In Iran, Pakistan, and India (Rajasthan) halogeton has adapted to irrigated agriculture where it grows in areas where evaporating drainage water leaves salt deposits. Cattle and camels will graze halogeton in its native habitat. It has always been puzzling that halogeton is not considered a threat to sheep in its native habitat.

Halogeton was first collected in the United States near Wells, Nevada in 1934. Many theories have been advanced as to how it could have possibly found its way to such an obscure location. The natural range of halogeton extends into the deserts of western China where seeds and herbage of the species are used in herbal medicine. A Chinese connection, through railroad construction workers or miners from China is no more far fetched than many of the other theories that have been put forth.

\section{Tumble Mustard}

Tumble mustard dominates a stage of succession before cheatgrass characterizes disturbed sagebrush/bunchgrass rangelands. At maturity the stem breaks at the soil surface and seeds are distributed as the wind tumbles the stiff stalks across the landscape. The small, mucilaginous seeds can germinate on the surface of seedbeds without soil coverage. In Asia tumble mustard is an ephemeral plant of the deserts. It is a species of the foothills rather than desert basins. Growth starts in April after snow melt and spring rains. 


\section{Scientific Names For Plants}

\begin{tabular}{ll}
\hline Common name & Scientific name \\
\hline Cheatgrass & Bromus tectorum L. \\
& Anisantha tectorum (L.) Nevski \\
Russian thistle & Salsola targus L. \\
& S. australis R. Brown \\
& S. kali var. tenuifolia Tausch \\
& S. iberica Sen. and Pau \\
& S. pestifer Nelson \\
Barbwire Russian thistle & Salsola paulsenii Litv. \\
Tamarisk & Tamarix \\
Ephedra & Ephedra \\
Haloxylon & Haloxylon \\
Halogeton & Halogeton glomeratus (Bieb) C. A. Mey \\
Tumble mustard & Sisymbrium altissimun L. \\
Medusahead & Taeniatherum caput-medusae (L.) Nevski \\
Kochia & Kochia \\
Greasewood & Sarcobatus \\
Saltbush & Atriplex \\
Sagebrush & Artemisia \\
Winterfat & Krascheninnikovia \\
Pigweed & Amaranthus \\
\hline
\end{tabular}

Plants are mature by the end of May. It is also a weed of irrigated fields in southern Turkmenistan, Northern Iran, Afghanistan, and Pakistan. It is absent from the Arabian countries and Israel. Being a weed of crop land, tumble mustard probably entered North America as a seed contaminant.

\section{Medusahead}

Medusahead was first described in the United States as Elymus caput-medusae by Howell in 1903. Nevski suggested in 1934 that the Russian types of medusahead should be classified in a separate genus Taeniatherum. Based on European and Russian literature, Jack Major of the University of California suggested in the $1960 \mathrm{~s}$ that Taeniatherum contained 3 geographic and morphologically distinct taxa: $T$. caput-medusae, $T$. asperum, and $T$. crinitum. After traveling in Russia, Major thought the correct classification for the material introduced to North America was Taeniatherum asperum. The Danish scientist Signe Frederiksen revised the genus in 1986 . He retained the same three taxa, but made them all subspecies of Taeniatherum caputmedusae.
Taeniatherum caput-medusae subspecies caput-medusae is largely restricted to Portugal, Spain, southern France, Morocco, and Algeria. It has been collected outside this area in Europe and Asia, But Frederiksen considers these outlying populations to be adventitious. Subspecies crinitum is found from Greece and the Balkans eastward into Asia. Subspecies asperum completely overlaps the distribution of the other 2 subspecies. All 3 subspecies integrate with each other.

In Asia medusahead is widespread on the low mountains and plateaus of Turkmenistan, Iran, Syria, and in the northern portions of Israel through the Jordan Valley to a latitude of $31^{\circ} \mathrm{N}$. It prefers soils rich in nitrogen and grows as both a rangeland and agronomic agriculture weed. It is often found on gravelly, stony soils.

The Danish botanist Hans Helbaek found carbonized seeds of medusahead in very early agricultural archaeologic sites in Iran. Along with cheatgrass and Russian thistle, the medusahead seeds were first found in strata that indicated the primitive agriculturalists were raising domesticated sheep and goats, instead of hunting wild animals. Apparently, these weeds have been a part of agriculture since the dawn of livestock domestication.

\section{The Future}

The post Cold War break up of the former USSR and the independence of the former Soviet Republics of Central Asia has opened this area for greater international travel and commerce. This offers the opportunity for exchange of additional self-invasive weed species. It is a twoway street. North American species of pig weed have proven to be nasty weeds in irrigated agriculture in Central Asia. Central Asia has also been a treasure house of germplasm for perennial grass breeders developing cultivars adapted to the Great Basin where they can be planted to biologically suppress the host of introduced weeds.

Vladimir Kostivkovsky, The Jacob Blaustein Institute for Desert Research, BenGurion University of the Negev, Sede Boker Campus, 84990, Israel.

James A. Young, USDA, ARS, 920 Valley Road, Reno, NV 89512. 